\title{
Seroprevalence and Clinico-Epidemiological Correlates of Hepatitis B Infection in Pregnancy at a Booking Antenatal Clinic, Federal Medical Centre, Yenagoa
}

\author{
Kotingo E. L. MBBS, DMAS, FMAS, FWACS \\ Allagoa D.O.B., Med (Pharm), MBBS, FWACS, DMAS, FMAS \\ Cert ART Cleverland USA, Dip HSM (Israel), FICS \\ Omietimi J. E., B Med Sc., MBBS, FWACS \\ Aigere Eos, MBBS, FWACS, FMCOG, DMAS \\ Oweisi P.W., MBBS, FWACS \\ John C. T., MBBS, FWACS, FMCOG, FRCOG, FICS \\ Department of Obstetrics and Gynaecology, Federal Medical Centre, \\ Yenagoa, Bayelsa State, Nigeria.
}

Doi: 10.19044/esj.2018.v14n6p279 URL:http://dx.doi.org/10.19044/esj.2018.v14n6p279

\begin{abstract}
Background: Hepatitis B virus infection is considered a major worldwide public health problem. While adults that acquire acute infection usually recover, the chronic type is ultimately fatal both to them and their foetuses. In endemic areas, individuals are infected by vertical transmission or infection in early childhood. The seroprevalence rates of Hepatitis B in pregnancy vary according to the endemicity of a given area with very high prevalence rates mostly reported among developing nations in Asia and Africa. Objective: To determine the seroprevalence of hepatitis B surface antigen in pregnant women attending the antenatal clinic, identify the clinical and epidemiological correlates for hepatitis B in pregnancy and to make evidence based recommendations on screening protocols for our obstetric population at the Federal Medical Centre, Yenagoa. Methodology: This is a descriptive cross sectional study. Two hundred and twenty (220) consecutive healthy pregnant women attending the antenatal booking clinic of the hospital who met the inclusion criteria were recruited into this study after pretest counselling and obtaining consent from them. This was tested for HBsAg with commercially available in vitro diagnostic kits (one step test strips). Data was collected via a structured interviewer administered questionnaire. Data entry and analysis was done using SPSS (statistical package for social sciences) 22 statistical package (SPSS Inc., Illinois, U.S.A). P value less than 0.05 was
\end{abstract}


taken as being significant. Results: The mean age of the pregnant women studied was 28.8 years \pm 5.2 while the mean parity was $1.20 \pm 1.16 .220$ pregnant women who came for antenatal booking were recruited into this study. Of these, $4.6 \%(n=10)$ were seropositive for hepatitis B surface antigen (HBsAg). Multiple sexual partners and Female circumcision were the significant risk factors for HBsAg seropositivity $(\mathrm{p}<0.05)$. There was no significant association with respect to a history of jaundice or contact with a jaundiced patient, previous blood transfusion, intravenous drug abuse or sharing of sharps, previous surgery, episiotomies or dilatation and curettage ( $>0.05)$. Conclusion: The intermediate endemicity of Hepatitis B virus infection in this study according to WHO classification, justifies the need for routine screening in pregnancy to identify and treat the infection accordingly as this will reduce the mother to child transmission. Multiple sexual partners and female circumcision are significant risk factors associated with Hepatitis $B$ virus infection in this environment. Active and passive immunization to infants of HBsAg seropositive mothers is advocated.

Keywords: Hepatitis B virus, Hepatitis B surface antigen, Hepatitis in pregnancy

\section{Introduction}

According to the Centre for Disease Control and Prevention, "Hepatitis" means inflammation of the liver. The liver is a vital organ that processes nutrients, filters blood and fights infection. When a liver is inflamed or damaged, its function can be affected. ${ }^{1}$

Historically, hepatitis B surface antigen ( $\mathrm{HBsAg}$ ) was formerly called Australia antigen because it was first described in the serum of an Australian aborigine in 1963. 2,3 Okochi and Murakami ${ }^{3}$ in 1968, discovered that the Australian antigen was related to type B Hepatitis.

The Hepatitis B virus (HBV) is the prototype member of the Hepadnaviridae (hepatotropic DNA virus) family. ${ }^{4,5} \mathrm{HBV}$ virions are doublestranded particles, 40 to $42 \mathrm{~nm}$ in diameter with an outer lipoprotein envelope that contains three related envelope glycoproteins (or surface antigens). ${ }^{5,6}$ Within the envelope is the viral nucleo-capsid, or core. ${ }^{6,7}$

Whereas Hepatitis may be caused by several viruses, it can also be caused by drugs or toxic chemicals with similar clinical manifestations of all forms. 4

Globally, more than 2 billion people have been infected with HBV at some time in their lives. ${ }^{8}$ In the past, it was estimated that over 350 million people were chronically infected worldwide and over 1 million die annually of HBV related chronic liver disease. ${ }^{9}$ However, currently an estimated 240 million people are chronically infected with Hepatitis B (defined as hepatitis 
B surface antigen positive for at least 6 months) and more than 780, 000 people die annually due to complications of Hepatitis B, including liver cirrhosis and liver cancer. ${ }^{10}$ Even with the decrease in the disease burden, globally it's still a major public health problem. Adults infected with HBV usually acquire an acute Hepatitis B infection and recover without sequelae, but 5-10\% ${ }^{6}$ may develop the chronic carrier state. Infected children rarely develop acute disease, but 25 - 90\% become chronic carriers. ${ }^{11}$ Neonates who acquire hepatitis will have an almost $90 \%$ risk of developing chronic HBsAg carrier state and chronic liver disease. Infants may also spread the disease to siblings and to their community. ${ }^{11}$

Transmission occurs when blood or body fluid of an infected person enters the body of a person who is not immune. ${ }^{12,13}$ In developing countries, the main routes of transmission are perinatal with Hepatitis B surface antigen (HBsAg) carrier mothers infecting their infants usually during birth. Other means of transmission are transfer of HBV through cuts, sexual transmission, transfusion of infected blood or blood products, needle stick injury, contamination of eye, re-use of HBV contaminated needles, syringes, lancets and instruments used in tribal markings, and possibly through blood sucking insects and bed bugs. ${ }^{14}$

Nigeria is classified among the group of countries endemic for HBV infection with a current infected population of 18 million. ${ }^{15}$ Despite the existence of a safe and effective vaccine, Nigeria has remained a hyperendemic area for HBV infection, with an estimated $12 \%$ of the population being chronic carriers. ${ }^{16}$

In South South Nigeria, Akani et $\mathrm{al}^{17}$ in Port Harcourt reported a seroprevalence of $4.3 \%$ and also Aigere et al ${ }^{18}$ in Irrua reported 6.8\%. In South West Nigeria, Agbede et al., ${ }^{19} 2007$ reported 5.7\% from Ilorin. 8.3\% from Zaria in North west Nigeria (Luka et al., 2008) ${ }^{20}$ and in North Central Nigeria, Mbaawuaga et al ${ }^{21}$ reported $11 \%$ to mention but a few. Consequently, studies on $\mathrm{HBV}$ infection in Nigeria have shown that the seroprevalence of the infection in pregnant women range from 3.8-13.3\%. ${ }^{16,22-28}$

Accepting, enshrining and implementing new policies and interventions by institutions, policy makers and administrators in resource or economically constrained countries must be evidence based particularly so in urban areas where the pace is set for rural and suburban areas to follow. Also, being a new training or research centre in the region, no previous study has been done on the seroprevalence and clinico-epidemiological correlates of Hepatitis B surface antigen in pregnancy at the Federal Medical Centre, Yenagoa. In view of these existing fact and the need to have a robust literature on viral Hepatitis in Africa, it's of utmost importance to enable us reappraise our continued dependence on Western data, while we provide evidence based local data for policy making. 


\section{Objectives}

The general objective is to determine the seroprevalence and clinicoepidemiological correlates of Hepatitis B surface antigen in pregnancy in Yenagoa.

The specific objectives are (1) To find out the seroprevalence of HBV in pregnant women that present in clinic. (2) To identify known risk factors for $\mathrm{HBV}$ infections in pregnant women. (3) To make evidence based recommendations on screening protocols for our obstetric population.

\section{Methodology}

Study Area

This study was carried out at the Antenatal clinic of the Federal Medical Centre, Yenagoa, Bayelsa state in the South-south region of Nigeria between $4^{\text {th }}$ September to $28^{\text {th }}$ October, 2016.

\section{Study design}

A descriptive cross sectional study.

\section{Inclusion criteria}

This included all pregnant women who presented for booking at the antenatal clinic of FMC Yenagoa and gave consent.

\section{Exclusion Criteria}

- $\quad$ This included all pregnant women who declined to participate.

- $\quad$ Patients who withheld their consent for inclusion in the study.

- $\quad$ Those immunised within the last six (6) months

\section{Sample size}

The sample size was calculated using the statistical formula ${ }^{29}$ based on reported prevalence rates of hepatitis B of $13.3 \%{ }^{16}$ from previous a study and a confidence interval of $95 \%$.

\section{Study population}

The minimum sample size was thus calculated to be 212 with an attrition of $20 \%$. However, a total of 220 consecutive healthy pregnant women attending the antenatal booking clinic of the hospital who met the inclusion criteria were recruited into this study after pre test counselling and obtaining consent from them. This was tested for HBsAg.

\section{Sample collection and processing}

Five millilitres $(5 \mathrm{ml})$ of peripheral venous blood was collected from consecutive subjects in the antenatal booking clinic into plain sterile bottles. 
Blood samples were centrifuged for ten minutes at 6,000 rpm, serum was obtained and stored at $-20^{\circ} \mathrm{C}$ until used.

Samples were analysed in batches with commercially available in vitro diagnostic kits (one step test strips). The HBsAg one step test is a rapid lateral flow immunoassay which qualitatively detects the presence of HBsAg in serum utilizing a combination of monoclonal and polyclonal antibodies to selectively detect elevated levels of $\mathrm{HBsAg}$ in serum. The membrane is percolated with anti- HBsAg antibodies on the test line region of the strip. During testing, the serum specimen reacts with the particles coated with antiHBsAg antibody. The mixture migrates upward on the membrane chromatographically by capillary action to react with anti- HBsAg antibodies on the membrane and generate a coloured line in the test region.

To serve as procedural control, a coloured line always appeared at the control line region indicating that proper volume of specimen had been added and membrane wicking had occurred. Tests in which two distinct red lines appeared, one in the control region and another in the test region, was regarded as positive. Tests in which only the control line was distinctly coloured red was recorded as negative while tests in which the control line fails to appear was regarded as invalid and was repeated.

Each sero-positive woman for HBsAg had a liver enzyme assay done particularly the serum transaminases (alanine and aspartate transaminase), as these have been shown to increase in active liver disease. The Randox test kit by RANDOX Laboratories Ltd., United Kingdom was used (because this is the standard test kit being utilized by the hospital). Levels above $12 \mathrm{U} / \mathrm{L}$ were regarded as elevated for both AST and ALT.

\section{Questionnaire}

Women were enrolled and underwent pretest counselling and were administered a structured interviewer- administered questionnaire.

\section{Data analysis}

Data was analysed using SPSS (statistical package for social sciences) 22 statistical package (SPSS Inc., Illinois, U.S.A). Univariate analysis for categorical variables was performed using chi-square. $\mathrm{P}$ value less than 0.05 was taken as being significant.

\section{Ethical considerations}

Approval for the study was obtained from the ethical committee of the Federal Medical Centre, Yenagoa. The study was carefully explained to the patients and their informed consent obtained before being recruited into the study. 


\section{Results}

A total of two hundred and twenty (220) pregnant women were interviewed.

The predominant age group was 20-29 years (50.0\%). The mean age is 28.8 years \pm 5.2 . Majority $(50.0 \%)$ of the respondents were from the Ijaw ethnic group and it is followed closely by the Igbo ethnic group (28.2\%). Most (96.8\%) of the respondents were Christians. Majority (41.8\%) of the respondents were involved in doing business as an occupation. Majority $(91.8 \%)$ also, of the respondents were married, and most of the marriages were of the polygamous type or setting (83.7\%). Most (77.8\%) had a secondary education. 
Table 1: Awareness, risk factors/transmission mechanisms of Hepatitis B viral infections.

\begin{tabular}{|c|c|c|c|c|}
\hline \multirow[t]{2}{*}{ Variables } & \multicolumn{2}{|c|}{ Frequency (\%) } & \multicolumn{2}{|r|}{ Total } \\
\hline & Yes & No & I don't know & \\
\hline Do you know about Hepatitis B infections? & $31(14.6)$ & $182(85.4)$ & $213(100.0)$ & \\
\hline $\begin{array}{l}\text { Can this virus be transmitted from person to person } \\
\text { If yes, through which means }\end{array}$ & $29(13.6)$ & $1(0.5)$ & $186(86.1)$ & $216(100.0)$ \\
\hline Blood/blood products & $15(51.7)$ & $0(0)$ & & \\
\hline Body fluids-urine, saliva & $2(6.9)$ & $0(0)$ & & \\
\hline Sexual intercourse & $10(34.5)$ & $0(0)$ & & \\
\hline Physical contact with infected person & $2(6.9)$ & $0(0)$ & & \\
\hline Total & $29(100.0)$ & $0(0)$ & & \\
\hline $\begin{array}{l}\text { Can these virus/infection be transmitted from mother } \\
\text { to baby }\end{array}$ & $12(5.5)$ & $0(0)$ & $206(94.5)$ & $218(100.0)$ \\
\hline If yes, when & & & & \\
\hline In utero & $2(16.7)$ & $0(0)$ & & \\
\hline During delivery & $4(33.3)$ & $0(0)$ & & \\
\hline Breastfeeding & $1(8.3)$ & $0(0)$ & & \\
\hline I don’t know & $5(41.7)$ & $0(0)$ & & \\
\hline Total & $12(100.0)$ & $0(0)$ & & \\
\hline Have you had more than one sexual partner in your life & $158(72.5)$ & $60(27.4)$ & & $218(100.0)$ \\
\hline Does your husband have other sexual partners & $6(2.8)$ & $26(12.0)$ & $185(85.3)$ & $217(100.0)$ \\
\hline Have you ever had sexually transmitted infections & $31(14.1)$ & $189(85.9)$ & & $220(100.0)$ \\
\hline Have you ever had blood /blood product transfusion & $13(6.0)$ & $205(94.0)$ & & $218(100.0)$ \\
\hline Do you share razor blades/needles with other people & $7(3.2)$ & $211(96.8)$ & & $218(100.0)$ \\
\hline $\begin{array}{l}\text { Have you ever engaged in injecting yourself with } \\
\text { illicit(hard) drugs }\end{array}$ & $3(1.4)$ & $216(98.6)$ & & $219(100.0)$ \\
\hline
\end{tabular}

Only $31(14.6 \%)$ of the respondents knew hepatitis B infection. If this virus could be transmitted from person to person, 29 (13.6\%) agreed that it could be transmitted from person to person; while $1(0.5 \%)$ said no, that it could not be transmitted from person to person; and $186(86.1 \%)$ did not know. Amongst those that agreed that the virus could be 
transmitted from person to person, $15(51.7 \%)$ said it is through blood/blood products; while $10(34.5 \%)$ said it is through sexual intercourse; and $2(6.9 \%)$ said it is through body fluids- urine, saliva and physical contact with infected persons.

Twelve $(5.5 \%)$ of the respondents said yes, that the virus could be transmitted from a mother to her baby, while 206 (94.5\%) did not know if there could be transmission of the viruses from a mother to her baby. Amongst those that said yes, $4(33.3 \%)$ said the infection occurs during delivery; while $5(41.7 \%)$ do not know how the transmission occurs; $2(16.7 \%)$ said it occurs in-utero; and $1(8.3 \%)$ said it occurs during breastfeeding.

Majority $(72.6 \%)$ of the respondents has had more than one sexual partner in their life. Most $(85.3 \%)$ of the respondents did not know if their spouses had other sexual partners. Eighty-five point nine percent (85.9\%) said they have not had sexually transmitted infections in the past; and $94 \%$ of the respondents has not had transfusion of blood and blood products; $96.8 \%$ do not share needles/blades with other people; and $98.6 \%$ do not inject illicit drugs.

Table 2: The seroprevalence of Hepatitis B amongst the different parity groups.

\begin{tabular}{lcc}
\hline Variables & Frequency $(\%)$ & \\
& Reactive & Non reactive \\
\hline Parity & $5(50.0)$ & $118(56.2)$ \\
Para 0-1 & $3(30.0)$ & $50(23.8)$ \\
Para 2-3 & $2(20.0)$ & $23(11.0)$ \\
Para 4-5 & $0(0)$ & $12(5.7)$ \\
Para 6-7 & $0(0)$ & $7(3.3)$ \\
Para 8-9 & $10(100.0)$ & $210(100.0)$ \\
Total & & \\
\hline
\end{tabular}

From the table above, the mean parity is $1.20 \pm 1.16$. It was observed that respondents with parity of $0-1$ had the highest $5(50.0 \%)$ reactive $\mathrm{HBsAg}$ result; and had the highest prevalence of $50.0 \%$.

Table 3: The seroprevalence of Hepatitis B amongst the different Gestational Age groups.

\begin{tabular}{llc} 
& Reactive & Non reactive \\
\hline GA (In weeks) & & \\
$1-12$ & $4(40.0)$ & $34(16.2)$ \\
$13-24$ & $2(20.0)$ & $89(42.4)$ \\
$25-40$ & $4(40.0)$ & $87(41.4)$ \\
Total & $10(100.0)$ & $210(100.0)$ \\
\hline
\end{tabular}

Those respondents with a booking gestational age of between one week and twelve weeks $(1-12)$, i.e. the first trimester; and those above twenty five weeks gestation i.e. those in third trimester gestation, were both found to 
be $40.0 \%$ reactive to HBsAg. Hence, the prevalence of hepatitis B was equal in respondents of both the first trimester and third trimester.

Table 4: The seroprevalence of Hepatitis B amongst those with history of abortion by Dilatation and Curettage.

Variables Frequency (\%)

\begin{tabular}{|c|c|c|}
\hline & Reactive & Non reactive \\
\hline \multicolumn{3}{|c|}{ History of abortion by D \& C } \\
\hline & $0(0)$ & $18(8.5)$ \\
\hline & $10(100.0)$ & $192(91.5)$ \\
\hline Total & $10(100.0)$ & $210(100.0)$ \\
\hline
\end{tabular}

Amongst those that have carried out abortion by dilatation and curettage, none were reactive to $\mathrm{HbsAg}$.

Table 5: The relationship between having more than one sexual partner and the seroprevalence of Hepatitis B infection.

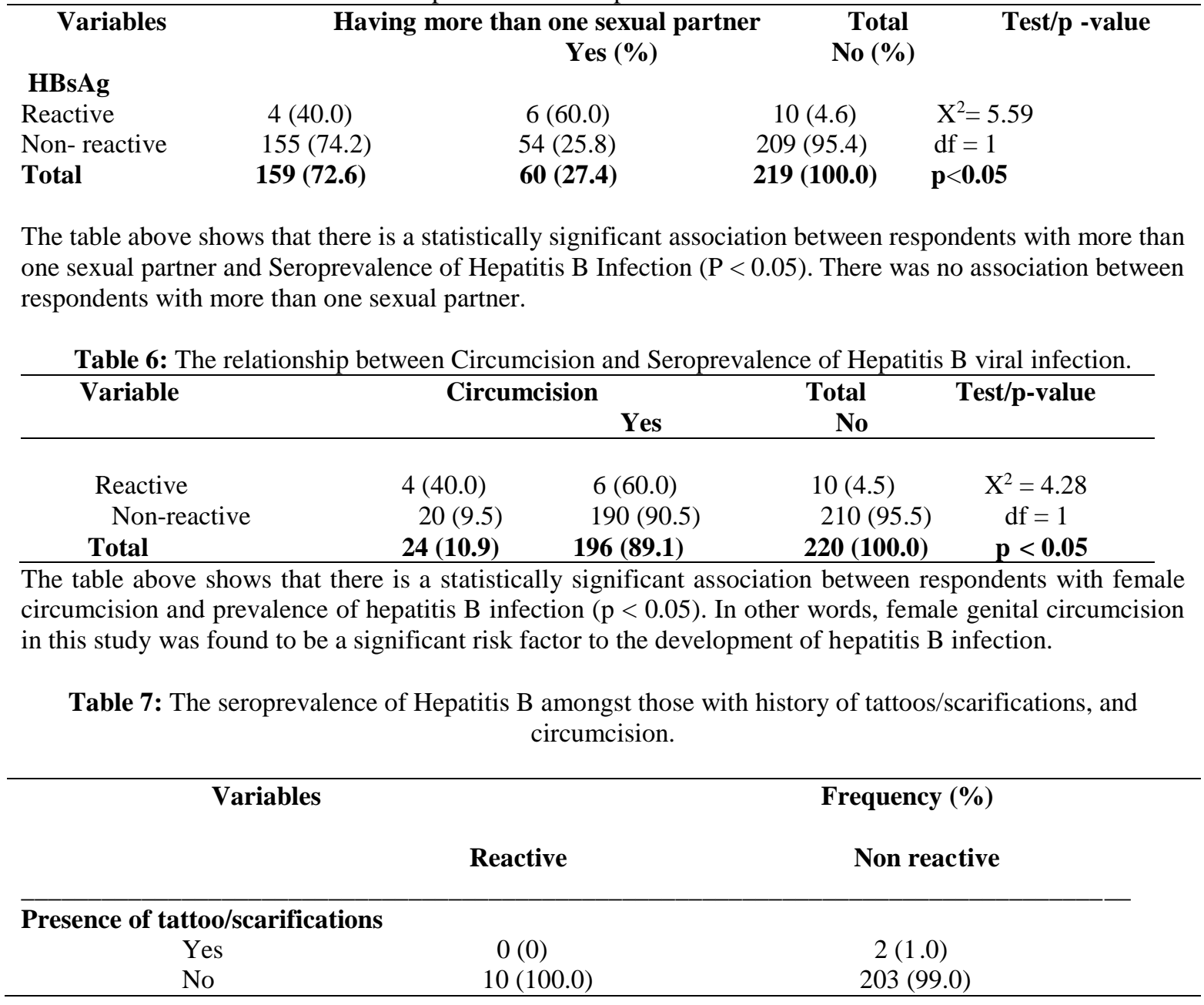


Total

History of Circumcision

Yes

No $10(\mathbf{1 0 0 . 0})$

$4(40.0)$

$6(60.0)$

$10(\mathbf{1 0 0 . 0})$
205 (100.0)

$19(9.0)$

$191(91.0)$

$210(100.0)$

From the table above, there was zero percent reactive results for both HBsAg test amongst the respondents that had tattoos/scarifications. Amongst those that were circumcised, $40.0 \%$ had positive HBsAg test.

Table 8: Relevant Clinical Parameters.

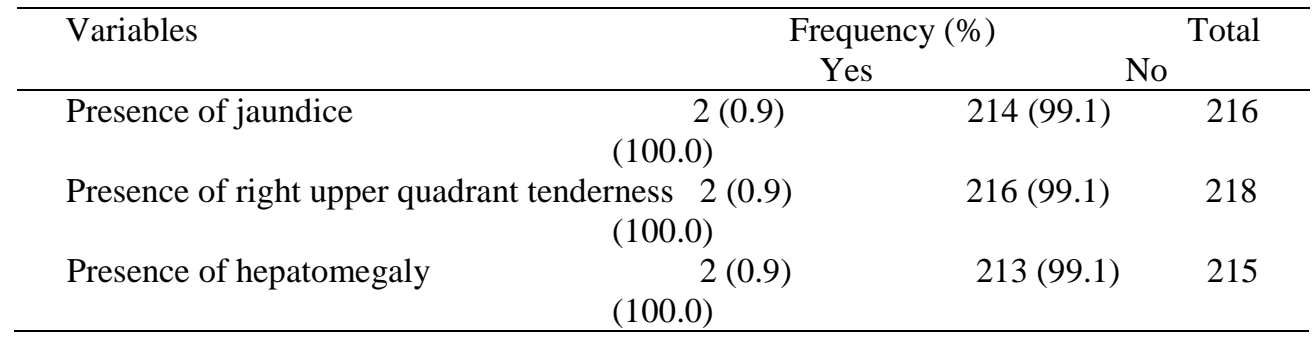

Only $0.9 \%$ of the respondents agreed that they have had jaundice, right upper quadrant tenderness, and hepatomegaly in the past.

Table 9: Results of Laboratory Investigations.

\begin{tabular}{lccc}
\hline Variables & Total & \multicolumn{2}{c}{ Frequency (\%) } \\
& Reactive & Non reactive & \\
\hline Result of HBsAg & $10(4.6)$ & $213(96.8)$ & 220 \\
& $(100.0)$ & & \\
& & & \\
\end{tabular}

Four point six percent $(4.6 \%)$ of the respondents were reactive to HBsAg.

All HBsAg seropositive pregnant women had normal serum aspartate aminotransferase (AST: normal <12U/L), alanine aminotransferase (ALT: normal <12U/L), and alkaline phosphatase values (ALP: normal, 9-35U/L).

\section{Discussion}

This is a hospital based study to determine the seroprevalence of HBsAg in an urban population of pregnant women and to evaluate the clinicoepidemiological correlates of risk factors in this group.

The seroprevalence of HBsAg in our pregnant women population was $4.6 \%$. This means that our pregnant women have an intermediate endemicity for hepatitis B virus infection according to the WHO classification ${ }^{30}$. This is similar to what was reported in Port Harcourt ${ }^{17}$, Enugu ${ }^{26}$, Ilorin ${ }^{19}$ and Irrua ${ }^{18}$ which were $4.3 \%, 4.6 \%, 5.7 \%$ and $6.8 \%$ respectively. A higher prevalence rate of $8.3 \%$ and $11.6 \%$ were reported in Zaria ${ }^{20}$ and Maiduguri ${ }^{31}$ respectively. A similar but slightly lower prevalence rate of $3.6 \%$ and $3.7 \%$ were reported 
among a study population in Abuja and Ethiopia respectively ${ }^{23,32}$. The prevalence in our study is however lower than the $12 \%$ in Taiwan or the $17.8 \%$ in Burkina Faso. ${ }^{33,34}$

In this study, the seroprevalence of Hepatitis B was found to be highest amongst the $30-39$ age group with $60.0 \%$ seroprevalence. There was a rise in the seroprevalence up to 39 years with an abrupt decline. Infection risks for Hepatitis $\mathrm{B}$ also increases with age naturally ${ }^{35}$. This may be due to a greater probability of exposure of these women to risk factors with age. However, other studies have reported 20-24 age group from Irrua ${ }^{18}$, Zaria ${ }^{16}$ and Ethiopia 32 . This may have been due to the lower number of subjects in the much older age groups in their reports and perhaps the indulgence in high risk practices such as unprotected sexual intercourse and tattooing by the younger age groups in their environment.

Ijaw women had the highest seroprevalence rates. This is simply because majority $(50.0 \%)$ of the subjects were from the Ijaw ethnic group which is the major ethnic group in this environs. The prevalence of HBsAg was more in nulliparous and primiparous females with a mean parity of 1.20 \pm 1.16 in this study. This can be explained by the increased rate of multiple sexual partners $(72.5 \%)$ in the past seen in our nulliparous and primiparous women as compared to our multiparous women. This finding was supported by Alegbeleye et al in Port Harcourt ${ }^{36}$. It is common reasoning that HBsAg prevalence would have been higher in multiparous women because of repeated risk of exposure to contaminated surfaces and instruments during delivery $16,18,20$. However, this was not the case in this study where the prevalence is higher in nulliparous and primiparous women.

The prevalence for HBsAg was highest in the first and third trimesters. This was comparable with findings by Aigere et $\mathrm{al}^{18}$ who observed that the third trimester in pregnant women had the highest prevalence rate. However, in this study, first trimester also topped the highest prevalence equally with third trimester.

Furthermore, in this study, notable risk factors such as intravenous drug use, blood transfusion, liver disease in our nulliparous and primiparous women respectively, were not associated with either HBV. None of the seropositive subjects had a history of blood transfusion. This may have been due to the aversion to receiving blood among our people. In Nigeria, illicit (hard) drugs including narcotics are strictly under control and attract severe sanctions thus limiting availability and or accessibility. This is why it's not surprising that as low as $1.4 \%$ of the women alluded to have taken illicit drugs in this study. Also, the poor economic situation may preclude the majority of our women of reproductive age from having access to these drugs even if they will dare the law ${ }^{27}$. Tattooing/scarifications $(0.9 \%)$ did not also contribute to HBsAg seropositivity. The cultural practice in this environment is on the 
decline, as such it is not a surprising occurrence. Amongst the surgical risk factors, female circumcision $(40 \%)$ even though a harmful traditional practice, posed a higher risk to HBsAg seropositivity than caesarean section (20\%) and appendectomy $(20 \%)$.

Previous studies have shown an inverse relationship between educational status and $\mathrm{Hbs} \mathrm{Ag}$ positivity with less educated women showing the highest positivity. ${ }^{37,38,39}$ However, in this study, educational level was not found to statistically, significantly influence knowledge of hepatitis B infections $(p>0.05)$. Educational level was not also found to significantly influence both knowledge of virus/infection transmission from person to person and having more than one sexual partner in life $(\mathrm{p}>0.05)$. The reason may not be farfetched without any form of prejudice, unlike in the Northern part of the country where most of the women are uneducated, there are more educated women in this southern part of the country. This finding is similar to the study in Port Harcourt. ${ }^{36}$

Majority $(72.5 \%)$ of the obstetric women has had a history of multiple sexual partners in their life and in addition, most $(85.3 \%)$ of them did not know if their spouses had other sexual partners. Of the HBsAg seropositive women, $40 \%$ had history of multiple sexual partners and there was a significant association between the history of multiple sexual partners and seropositivity for HBsAg. There was a significant association between the history of multiple sexual partner and seropositivity for $\mathrm{HBsAg}$. Dilatation and Curretage was not found to statistically, significantly influence Hepatitis B viral infections ( $p$ > 0.05). This could be because most of the $\mathrm{D}$ and $\mathrm{C}$ was done in the hospital and the instruments used could have been well sterilized. These findings were similar to reports in Irrua ${ }^{18}$. However, it was found in their study that Dilatation and curettage had a significant contribution to $\mathrm{HBsAg}$ seropositivity.

Previous screening reports show that universal prenatal screening for $\mathrm{HBsAg}$ is cost effective if the HBsAg carrier rate is greater than $0.06 \% .{ }^{40} \mathrm{With}$ a seroprevalence of $4.6 \%$, the findings of this study affirmed the need for routine HBsAg screening among pregnant women in developing countries particularly in urban areas like Yenagoa for rural/suburban areas to mimic.

\section{Conclusion}

The intermediate endemicity of Hepatitis B virus infection in this study according to WHO classification, justifies the need for routine screening in pregnancy and to treat the infection accordingly as this will reduce the mother to child transmission of the virus. Multiple sexual partners and female circumcision are significant risk factors associated with Hepatitis B virus infection in this environment. Active and passive immunization to infants of HBsAg seropositive mothers is advocated. 


\section{Recommendations}

- $\quad$ Sensitization and routine screening for Hepatitis B virus in pregnancy.

- Treatment of Hepatitis B virus infection in pregnancy to reduce mother-to-child transmission.

- $\quad$ Availability and accessibility of Hepatitis B immunoglobulin to babies born to HBsAg-positive mothers by Government and Nongovernmental organizations.

- $\quad$ Sensitization and vaccination of adults against HBV especially those at risk e.g multiple sexual partners etc.

- Campaign against Female Genital Mutilation.

\section{Acknowledgement}

My unalloyed gratitude goes to all the consultants and residents in the department, for their constructive criticisms and suggestions during the course of writing this dissertation as partial fulfilment of the part II fellowship Examination of the West African College of Surgeons, Faculty of Obstetrics and Gynaecology.

\section{References:}

1. Centre for Disease Control and Prevention (2010); Division of Viral Hepatitis. www.cdc.gov/hepatitis; pp. 21-1073.

2. Blumberg B S, Gerstley B S., Hungerford D A, London WT, Sutnik AJ (1967). A serum Antigen (Australian Antigen) in Down's syndrome, Leukemia and Hepatitis. Ann Int Med, 66: pp. 924 -31.

3. Okochi K, Murakami S (1968). Observations on Australia Antigen in Japanese. Vox Sang; 15: pp. 375 -85

4. Chapman RW, Collier JD, Hayes PC (2006). Liver and Biliary tract diseases. In Nicholas A. B, Nikki R.C, Brian R.W et al (Eds): Davidson's Principles and Practice of Medicine, 20th Edition; pp. 962968.

5. Dienstag JL, Isselbacher K.J (2001): Acute Viral hepatitis. In Braunwald E, Fauci AS, Kasper DL, et al (eds): Harrison's principles of Internal medicine, 15th ed. New York, McGraw-Hill; p. 1742.

6. Cunningham FG, Leveno KJ, Bloom L.S. et al (2005): Hepatic, biliary tract and pancreatic disorders. Williams Obstetrics, 22nd ed. New York, McGraw-Hill; pp. 1125-1137.

7. Guberman C, Greenspoon J, Goodwin MT. Gastrointestinal Disorders (2007). In: DeCherney AH, Nathan L, Goodwin MT, Laufer N, eds. Current diagnosis and treatment; 10th ed. NewYork: McGraw-Hill: pp. $380-385$.

8. Uneke CJ, Ogbu O, Inyama. PU, Anyanwieg.I., Njoku MO, Idoko JH (2005). Prevalence of hepatitis B surface antigen among blood donors 
and Human immunodeficiency Virus - infected patients in Jos, Nigeria. Mem Inst Oswaldo Cruz, Rio de Janeiro; 100 (1): pp. 13 - 16.

9. Alter M.J (2003). Epidemiology of hepatitis B in Europe and Worldwide. J. Hepatol; 39(s1): pp. 64-9.

10. Lozano R, Naghavi M, Foreman K, Lim S, Shibuya K, Aboyans V, Abraham J, et al (2012). Global and regional mortality from 235 causes of death for 20 age groups in 1990 and 2010: a systematic analysis for the Global Burden of Disease Study 2010. Lancet 2012; 380: pp. 20952128.

11. Juszozyk J (2000). Clinical course and consequences of hepatitis B infection. Vaccine; 18(1): pp. 23-25.

12. Centre for Disease control and prevention (2003). Division of viral hepatitis, National Centre for infectious Disease, Viral Hepatitis B. htt:/www.cdc.gov/ncidod/cliseases/none hepatitis/b/fact.htm.

13. Centre for Disease control and prevention (2001). Hepatitis B Vaccine. Vaccine information statement. http://www.cdc.gov/hepatitisnone.

14. Ferriara MS (2000). Diagnosis and treatment of Hepatitis B. Rev Soc Bras Med Trop; 33: pp. 389-40

15. Ojo OO, Anibijuwon II (2009). Determination of antibodies to hepatitis B virus in pregnant women in Akure, Ondo state, Nigeria. Cont. J. Microbiol. 3:6-10.

16. Jatau E, Yabaya A (2009). Seroprevalence of hepatitis B virus in pregnant women attending a clinic in Zaria Nigeria. SWJ; 4(2): pp. $7-$ 9.

17. Akani C.I, Ojule A.C. Opurum. H.C, Ejilemele A.A (2005) Seroprevalence of $\mathrm{HbsAg}$ in pregnant women in Port Harcourt Nigeria. Post graduate medical journal; 12(4): pp. 266-270.

18. Aigere EOS, Okusanya BO, Isabu PA, Eifediyi RA, Eruzegbua S (2013). Clinico epidemiological correlates of Hepatitis B infection in Suburban population of pregnant women in Niger Delta Region of Nigeria. Nig. Qt. J. Hosp. Med; 23(3): pp. 205-209

19. Agbede OO, Iseniyi JO, Kolewale MO, Ojuowa A (2007). Risk factors and seroprevalence of hepatitis B antigenaemia in mothers and their preschool children in Ilorin, Nigeria. Therapy; 4(1): pp. 67-72.

20. Luka SA, Ibrahim MB, Iliya SN (2008). Seroprevalence of hepatitis B surface antigen among pregnant women attending Ahmadu Bello University Teaching Hospital, Zaria. Nigerian Journal of parasitology; 29(1): pp. 38-41.

21. Mbaawuaga EM, Enenebeaka MNO, Okopi JA, Damen JG (2008). Hepatitis B virus infection (HBV) among pregnant women in Makurdi, Nigeria. Afr J Biol Res; 11: pp. 155-159. 
22. Ezegbudo CN, Agbonlahor DE, Nwobu GO, Igwe CU, Agba MI, Okpala HO (2004). The seroprevalence of Hepatitis B surface antigen and Human immunodeficiency virus (HIV) among pregnant women in Anambra state. Shiraz E-medical J; 5(2): pp. 1-8.

23. Bassey EB, Moses AE, Udo. SM, Umo AN (2009). Parallel and overlapping human Immunodeficiency Virus, hepatitis B and C virus infections among pregnant women in the Federal capital territory, Abuja, Nigeria. Online J. Health Allied Scs.; 8(1): pp. 1-4.

24. Ades AE, Parker S, Walker J, Cubitt WD, Jones R (2000). HCV prevalence in pregnant women in the UK. Epidemiol Infect; 125: pp. 399-405.

25. Rasha ME, Ahmed AD, Mohamed AE, Mubarak SK, Ishag A (2007). Hepatitis B Virus and hepatitis C virus in pregnant women. Virology Journal; 4: p. 104.

26. Obi SN, Onah HE, Ezugwu FO (2006). Risk factors for hepatitis B infection during pregnancy in a Nigerian obstetric population. J. Obstet Gynaecol; 26(8): pp. 770-772.

27. Onakewhor JUE, Okonofua FE (2009). Seroprevalence of hepatitis C viral antibodies in pregnancy in a tertiary health facility in Nigeria. Nig. J. Clin. Pract; 12(1): pp. 65-73.

28. Blumberg B S, Gerstley B S., Hungerford D A, London WT, Sutnik AJ (1967). A serum Antigen (Australian Antigen) in Down's syndrome, Leukemia and Hepatitis. Ann Int Med, 66: pp. 924 -31.

29. Araoye MO (2003). Subjects Selection. In: Research Methodology with statistics for Health and Social sciences. Ilorin. Nathadex publishers: pp. 115-129.

30. Chen C, Chang M (2010). Hepatitis B and pregnancy; The scientific basis for perinatal prevention. Cambridge J Online; 21: pp. 89-113.

31. Imarengiaye CO, Enoselease ME, Iribogbe PE, Ehigiegba AE (2006). Risk of transfusion transmitted Hepatitis $\mathrm{C}$ virus in a tertiary hospital in Nigeria. Public Health; 120: pp. 274-278.

32. Awole M, Gebre-selassie S (2005). Seroprevalence of hepatitis B surface antigen and its risk factors among pregnant women in Jimma, South-west Ethiopia. Ethiopia J Health Devt: 19(1): pp. 45-50.

33. Lin HH, Kao JH, Chang TC, Hsu HY, Chen DS (2003). Secular trend of age specific prevalence of hepatitis B surface and e- antigenaemia in pregnant women in Taiwan. Journal of medical virol; 69: pp. 466470.

34. Collenberg E, Ouedraogo T, Ganame J, Ackenscher H, Kynast-wolf $\mathrm{G}$, Becher H, et al (2006). Seroprevalence of 6 different viruses among pregnant women and blood donors in rural and urban Burkina Faso: A 
comparative analysis. Journal of medical virology; 78(5): pp. $683-$ 692.

35. Al-Shamahy H (2000). Prevalence of hepatitis B surface antigen and risk factors for HBV infection on a sample of healthy mothers and their infants in Sana A, Yemen. Ann Saudi med; 20(5): 464-467.

36. Alegbeleye JO, Nyengidiki TK and Ikimalo JI (2013). Maternal and neonatal seroprevalence of hepatitis B surface antigen in a hospital based population in South-South Nigeria. Int. J. Med. Med. Sci. Vol. 5(5), pp.241-246.

37. Pennap GR, Osanga ET, Ubam A (2011). Seroprevalence of hepatitis B surface antigen among pregnant women attending antenatal clinic in Federal Medical Center, Keffi, Nigeria. Res J. Med b Sci; 51 (2): 80-82.

38. Eke AC, Eke UA, Okafor CI, Ezebiaku I. U, Ogbuagu C (2011). Prevalence, correlates and pattern of Hepatitis B surface antigen in a low resource setting. Virol J; 8:12.

39. Ndams IS, Joshua IA, Luka SA, Sadiq HO (2008). Epidermiology of hepatitis B infection among pregnant women in Minna, Nigeria. Sci World J; 3(3): 5-8.

40. Kao JH (2002). Hepatitis B viral genotypes; Clinical relevance and molecular characteristics. J Gastroenterol Hepatol: 17: pp. 643-650. 